\title{
Microbial Removal of Cyanide Compounds and Soil Cyanide by Klebsiella oxytoca
}

\author{
Siyanür Bileşiklerinin ve Topraktaki Siyanürün \\ Klebsiella oxytoca ile Mikrobiyal Giderimi
}

\author{
Research Article
}

Nermin Hande Avcıoğlu* and Işıl Seyis Bilkay

Hacettepe University, Faculty of Science, Department of Biology (Biotechnology), Beytepe, Ankara, Turkey.

\section{A B S T R A C T}

\begin{abstract}
n this study, Klebsiella oxytoca ATCC 13182 degraded potassium cyanide, potassium hexacyanoferrate(II) trihydrate, potassium tetracyanonickelate(II) hydrate and sodium ferrocyanide decahydrate with the efficiencies of $100 \%, 87 \%, 78.5 \%$ and $27.5 \%$, respectively. Additionally, optimal conditions for cyanide biodegradation were found as $30^{\circ} \mathrm{C}, 100 \mathrm{rpm}$ and $\mathrm{pH}=7.0$ at the concentration of $0.5 \mathrm{mM}$ potassium cyanide in the biodegradation medium. Furthermore, K. oxytoca degraded potassium cyanide in the presence of different ions ( $\mathrm{Mg}, \mathrm{Ni}, \mathrm{Co}, \mathrm{Fe}, \mathrm{Ca}, \mathrm{Cr}, \mathrm{As}, \mathrm{Cu}$ and $\mathrm{Zn}$ ) and as a result the growth amount of $\mathrm{K}$. oxytoca decreased as the ion concentrations increased. It is also observed that 5:10 (v:v) concentration of sterile crude extract of $K$. oxytoca degraded $73.5 \%$ of the cyanide content in the biodegradation media in the first 24 hours. Finally, it is examined that $6 \mathrm{mgkg}^{-1}$ and $240 \mathrm{mgkg}^{-1}$ cyanide in soil samples were also degraded partially by $\mathrm{K}$. oxytoca's culture and sterile crude extract.
\end{abstract}

\section{Key Words}

Klebsiella oxytoca, cyanide, sterile crude extract, biodegradation.

\section{öz}

u çalışmada, Klebsiella oxytoca ATCC 13182 suşunun potasyum siyanür, potasyum hekzasiyanoferrat(II) trihidrat, potasyum tetrasiyanonikelat(II) hidrat ve sodyum ferrosiyanür dekahidratı sırasıyla $\% 100, \% 87$, \%78.5 ve \%27.5 oranında bozunduğu belirlendi. Buna ek olarak, siyanür biyobozunma optimal koşullar 0.5 $\mathrm{mM}$ derişimde potasyum siyanür içeren biyobozunma besiyerinde, $30^{\circ} \mathrm{C}, 100 \mathrm{rpm}$ ve $\mathrm{pH} 7.0$ olarak bulundu. Ayrıca, K. oxytoca potasyum siyanürü farklı iyonların varlığında da (Mg, Ni, Co, Fe, Ca, Cr, As, Cu ve Zn) yıktığı gözlendi ve sonuç olarak K. oxytoca'nın üreme miktarının iyon derişimi arttıkça azalma gösterdiği belirlendi. K. oxytoca'nın 5:10 (h:h) derişimdeki steril kültür süpernatanının da ilk 24 saatte biyobozunma besiyerindeki siyanürün \%73.5'ünü parçaladıgı gözlendi. Son olarak, K. oxytoca kültür ve steril kültür süpernatanının 6 mgkg ${ }^{1}$ ve $240 \mathrm{mgkg}^{-1}$ siyanür içeren toprak örneklerindeki siyanürü de kısmen bozunmaya uğratabildiği belirlendi.

\section{Anahtar Kelimeler}

Klebsiella oxytoca, siyanür, steril kültür özütü, biyobozunma.

Article History: Received: Mar 02, 2017; Revised: July 23, 2017; Accepted: Sep 21, 2017; Available Online: Dec 25, 2017. DOI: 10.15671/HJBC.2018.193

Correspondence to: N.H. Avcıoğlu, Hacettepe University, Faculty of Science, Department of Biology (Biotechnology), Ankara, Turkey. 


\section{INTRODUCTION}

B

means of

discharging untreated wastewaters from industrial processes and cyanide formation by different organisms such as bacteria, algae, fungi, plants and animals, cyanide accumulation becomes an important issue for environmental health because of its toxic, carcinogenic and mutagenic effects [1-5] In this respect, it is significant to take precautions against cyanogen compounds in nature in order to protect environment.

In cyanide treatment processes, both of chemical and biological systems are being used in order to treat cyanogen compounds efficiently. Among them, although chemical methods detoxify cyanide in a short time, these methods use toxic chemicals, produce toxic sub products, require extra equipment and need high processing costs. However, when biological methods are used in cyanide treatment procedures, cyanide removal may be done with low costs and end products are generally nontoxic. Therefore, biological treatment methods are known as environmentally friendly [6-8]. In this respect, Pseudomonas pseudoalcaligenes, Pseudomonas fluorescens, Pseudomonas putida, Pseudomonas aureofaciens, Azotobacter vinelandii, Bacillus pumilus, Paracoccus sp. and lots of other microorganisms were investigated according to their cyanide removal capabilities in different researches and as a result, these microorganisms are being used as removal agents for cyanide and some other toxic compounds $[2,8,9-12]$.

In this study, it is aimed to determine the cyanide biodegradation efficiencies of different $K$. oxytoca strains and to investigate optimization conditions and activator/inhibitor effects of different ions as contaminants on this biodegradation process of most effective cyanide biodegrading strain. Additionally, the usability of sterile crude extract of $K$. oxytoca strain was also examined in cyanide removal instead of K. oxytoca culture. In the last part of this study, different concentrations of cyanide containing soil samples were prepared and the efficiencies of $K$. oxytoca strains' culture and sterile crude extract on cyanide removal of these soil samples were also investigated.

\section{MATERIALS and METHODS}

\section{Bacterial Strains}

Cyanide degradation efficiencies of 6 different K. oxytoca strains were investigated in this study. Accordingly, K. oxytoca was inoculated into Luria Bertani Broth and incubated for log phase. After the incubation period, the absorbance of the culture was adjusted to $A_{600 \mathrm{~nm}}=1$ and it was inoculated with the concentration of $1: 10(\mathrm{v}: \mathrm{v})$ into the biodegradation media $(\mathrm{pH}=7)$ containing $\left(\mathrm{gL}^{-1}\right)$ 1 glucose, $0.5 \mathrm{~K}_{2} \mathrm{HPO}_{4}, 0.5 \mathrm{KH}_{2} \mathrm{PO}_{4}, 0.05 \mathrm{MgSO}_{4}$ [10]. Incubation period was carried out at $30^{\circ} \mathrm{C}$, 100 rpm for 5 days (Certomat BS-l; Sartorius, Tokyo, Japan). At the end of the incubation period, the most effective strain in cyanide degradation process was selected in order to use in the rest of this study. Additionally, this strain was identified by using 16S rRNA analysis (Refgen, Ankara, Turkey) and it is determined as $99.9 \%$ similar to $K$. oxytoca ATCC 13182 [13].

\section{Analysis of Biodegradation Products}

Residual cyanide concentration was assessed by using picric acid method [14] and nesslerization was used to evaluate the concentration of ammonia in the biodegradation medium [15]. Additionally, the growth amount of $K$. oxytoca cultures was measured by spectrophotometrically (UV 1700, Shimadzu, Tokyo, Japan) at $A_{600 \mathrm{~nm}}$.

\section{Biodegradation Capability of $K$. oxytoca Against Different Cyanide Sources}

Selected $K$. oxytoca strain was inoculated into the biodegradation media containing different cyanide sources (potassium cyanide, potassium hexacyanoferrate(II) trihydrate, potassium tetracyanonickelate(II) hydrate and sodium ferrocyanide decahydrate) separately with the concentration of $0.5 \mathrm{mM}$ and incubation period was carried out at $30^{\circ} \mathrm{C}, 100 \mathrm{rpm}$ for 5 days (Certomat BS-I; Sartorius, Tokyo, Japan). The experiment was performed in triplicate.

\section{Investigation of Optimal Cyanide Biodegradation Conditions for K. oxytoca}

Incubation period (1 to 6 days), initial $\mathrm{pH}$ value (3 to 10 ), incubation temperature $\left(20^{\circ} \mathrm{C}\right.$ to $50^{\circ} \mathrm{C}$ ), initial $\mathrm{KCN}$ concentration $(0.25 \mathrm{mM}-2 \mathrm{mM})$ and 
rotation speed (0 to $200 \mathrm{rpm}$ ) were investigated in order to examine the optimal conditions for cyanide biodegradation by using $K$. oxytoca strain. All of these experiments were performed in triplicate.

\section{Effect of Ions on Cyanide Biodegradation Process}

In this part, activator and inhibitor effects of different concentrations $(0.1 \mathrm{mM}, 0.25 \mathrm{mM}$ and $0.5 \mathrm{mM}$ ) of ions $(\mathrm{Mg}, \mathrm{Ni}, \mathrm{Co}, \mathrm{Fe}, \mathrm{Ca}, \mathrm{Cr}, \mathrm{As}$, $\mathrm{Cu}$ and $\mathrm{Zn}$ ) on cyanide biodegradation process were investigated. Accordingly, K. oxytoca strain $\left(A_{600 \mathrm{~nm}}=1.0\right)$ was inoculated with the concentration of $1: 10 \quad(\mathrm{v}: \mathrm{v})$ into the ion supplemented biodegradation media and incubation period was carried out at $30^{\circ} \mathrm{C}, 100 \mathrm{rpm}$ for 5 days (Certomat BS-I; Sartorius, Tokyo, Japan). The experiments were performed in triplicate.

\section{Effect of Sterile Crude Extract of $K$. oxytoca on Cyanide Biodegradation Process}

Biodegradation capability of sterile crude extract of $K$. oxytoca was also investigated in this study. Accordingly, K. oxytoca was inoculated into cyanide biodegradation media with the concentration of 1:10 (v:v) and incubated in a rotary shaker (Certomat BS-I; Sartorius, Tokyo, Japan) at $30^{\circ} \mathrm{C}, 100 \mathrm{rpm}$ for 5 days. After the incubation period, culture was centrifuged at $4000 \mathrm{rpm}$ for 5 minutes (Eppendorf Centrifuge 5417R; Hamburg, Germany). Supernatant was taken and sterilized by $0.45 \mu \mathrm{M}$ cellulose acetate filter (Millipore) in order to obtain sterile crude extract of $K$. oxytoca. Accordingly, different concentrations of sterile crude extract [1:10, 2:10, 3:10, 4:10 and 5:10 (v:v)] were inoculated into the biodegradation media separately. Incubation period was carried out at $30^{\circ} \mathrm{C}$ and at $100 \mathrm{rpm}$ (Certomat BS-I; Sartorius, Tokyo, Japan). The experiment was performed in triplicate.

\section{Cyanide Removal in Soil}

Soil samples were collected from Beytepe/Ankara, Turkey and sterilized with autoclave at $121 \mathrm{C}, 1.5$ atm for $15 \mathrm{~min}$. After the sterilization period, 6 $\mathrm{mgkg}^{-1}$ and $240 \mathrm{mgkg}^{-1}$ cyanide containing soil media were prepared in order to examine cyanide removal efficiencies of $K$. oxytoca's culture and its sterile crude extract. Accordingly, culture and sterile crude extract of $K$. oxytoca strain were inoculated into the biodegradation media with the concentrations of 1:10 ( $\mathrm{v}: \mathrm{v})$ separately and incubation period was carried out at $30^{\circ} \mathrm{C}, 100$ rpm and 5 days in a rotary shaker (Certomat BSI; Sartorius, Tokyo, Japan). The experiment was performed in triplicate.

\section{RESULTS and DISCUSSION}

By means of discharging untreated wastewaters through the soil and water from different industrial processes, cyanide compounds dissociate in water to its ions and form complexes with heavy metals rapidly which represent different toxicity and stability [16]. Accordingly, these metal cyanide complexes metabolize or transform into nontoxic end products by microorganisms as a carbon and nitrogen source [8]. Therefore, in this study, 6 different $K$. oxytoca strains were investigated according to their cyanide biodegradation abilities and Kox1 strain which was identified as K. oxytoca ATCC 13182 by using $16 \mathrm{~S}$ rRNA analysis (Refgen, Ankara, Turkey), was found to be the most effective one in cyanide removal (Figure 1).

In this study, it is observed that, $K$. oxytoca degraded tetracyanonickelate with an efficiency of $27.5 \%$ under unoptimized conditions (Figure 2). Yanase et. al. [17] found that tetracyanonickelate was degraded by using cell free extracts of bacteria and fungi and these microorganisms degraded it with the efficiencies of $20-30 \%$ and $100 \%$ in about 1 month, respectively. On the other hand, whereas hexacyano complexes of iron, which is known as ferro cyanides, are stable and recalcitrant cyanide compounds [18], K. oxytoca strain also degraded potassium hexacyanoferrate(II) trihydrate and sodium ferrocyanide decahydrate in unoptimized conditions (Figure 2). Accordingly, our results indicated the usability of $K$. oxytoca in the biotreatment processes of wastewaters contaminated with different cyanogen compounds.

Furthermore, although in different researches, it is determined that $A$. tumefaciens degraded cyanide with a percentage of 75 [19], $P$. fluorescens with a percentage of 78.9 [8] and 


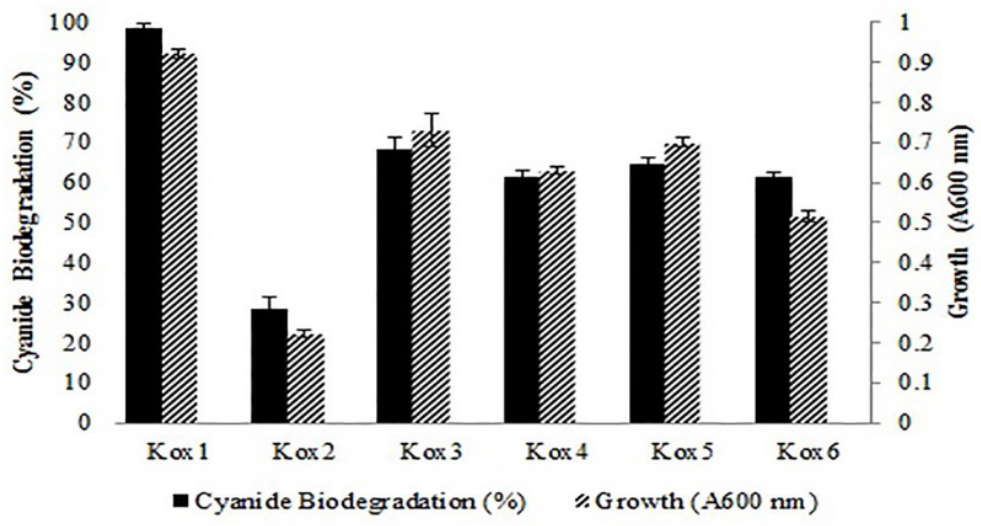

Figure 1. Biodegradation of potassium cyanide by different $K$. oxytoca strains.

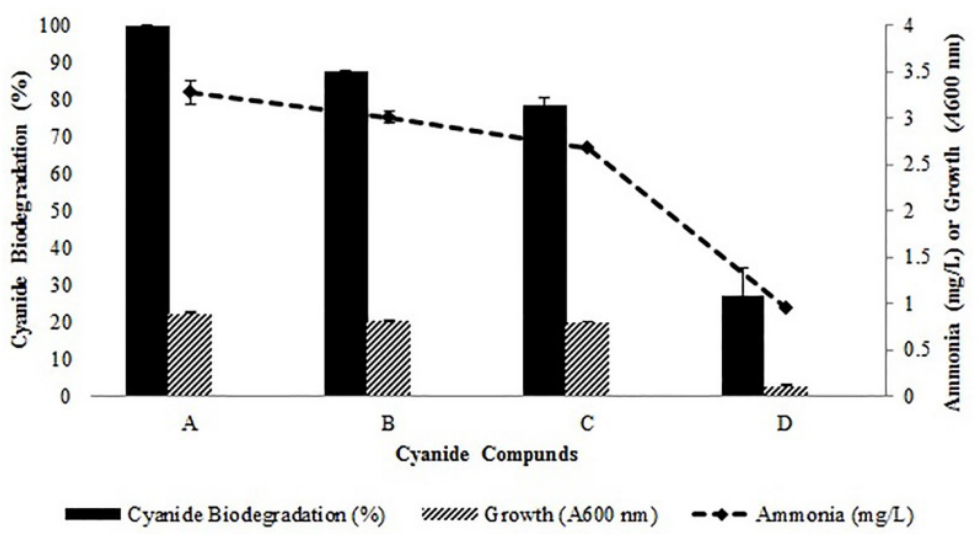

Figure 2. Biodegradation ability of K. oxytoca strain against different cyanide compounds.

(A:Potassium cyanide; B: Potassium hexacyanoferrate(II) trihydrate; C: Sodium ferrocyanide decahydrate and D: Potassium tetracyanickelate (II) hydrate).

these strains are indicated as usable agents in cyanide biodegradation processes, $K$. oxytoca degraded over $70 \%$ of the cyanide content in the biodegradation media in the first 24 hours of the incubation period in this study (Figure 3a). Additionally, in previous studies $P$. fluorescens degraded $0.25 \mathrm{mM} \mathrm{KCN}$ and it is found that growth and cyanide degradation amount decreased as the concentration increased [20]. However, in this study $\mathrm{K}$. oxytoca degraded $1 \mathrm{mM} \mathrm{KCN}$ over $80 \%$ efficiency and it also degraded $1.5 \mathrm{mM}$ and $2 \mathrm{mM}$ $\mathrm{KCN}$ with a rotation speed of $100 \mathrm{rpm}$ (Figure $3 \mathrm{~b}$ and Figure $3 \mathrm{c}$ ). In this respect, these results indicated that $K$. oxytoca strain is an important agent for biodegradation processes.

Additionally, $\mathrm{pH}$ of the industrial wastes in which cyanide are being used or cyanogen compounds are formed, is approximately 7.5 to 10.0 [21]. In this respect, microorganisms which may be used in these cyanide degradation processes must have a wide range of $\mathrm{pH}$ toleration to grow and to form biodegradation enzymes. In this study, $K$. oxytoca exhibited a great $\mathrm{pH}$ tolerance since this strain degraded cyanide over $70 \%$ between the $\mathrm{pH}$ values of $3-10$ and over $90 \%$ between the $\mathrm{pH}$ values of 6-8 (Figure $3 \mathrm{~d}$ ) which is resemble with other researches which found as $\mathrm{pH}=7.5$ for Cryptococcus humicola [22], $\mathrm{pH}=$ 7-8.5 for Azotobacter vinelendii [10] and $\mathrm{pH}=7-8$ for a consortium including Bacillus sp., Klebsiella sp. and Pseudomonas sp. [23].

In previous researches, optimal cyanide biodegradation temperatures were found as $25^{\circ} \mathrm{C}$ for Cryptococcus humicola [22] and $35^{\circ} \mathrm{C}$ for Serratia marcescens [24]. Accordingly, in this study whereas optimal temperature for cyanide biodegradation by using $K$. oxytoca is found as $30^{\circ} \mathrm{C}$, it is also examined that this 


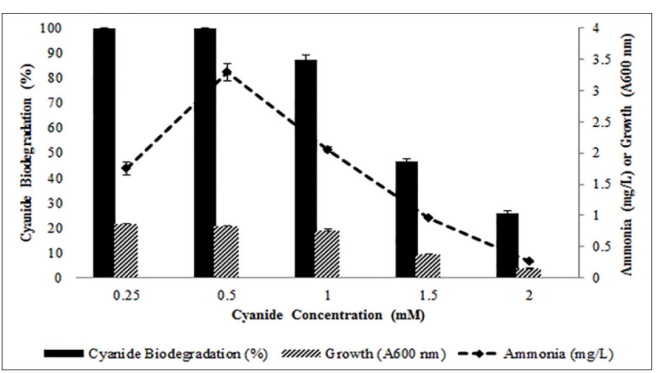

(b)

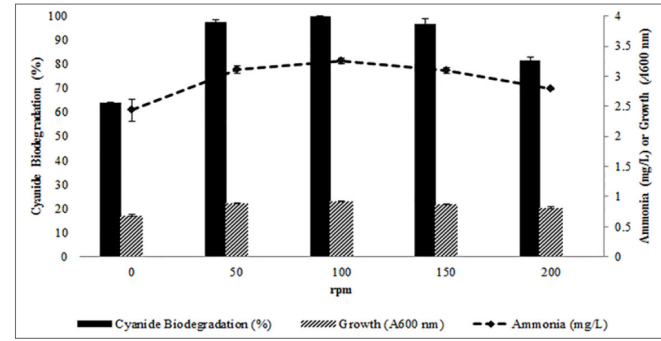

(c)

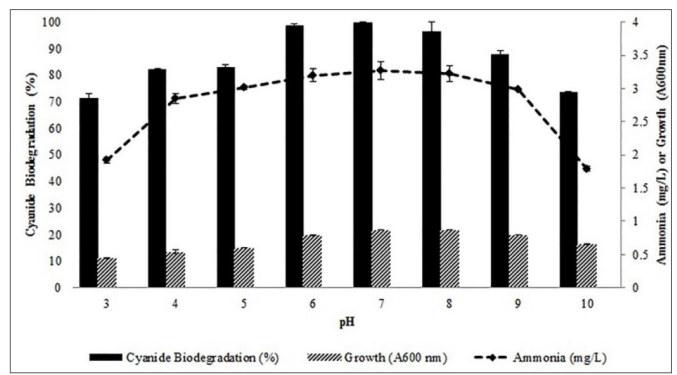

(d)

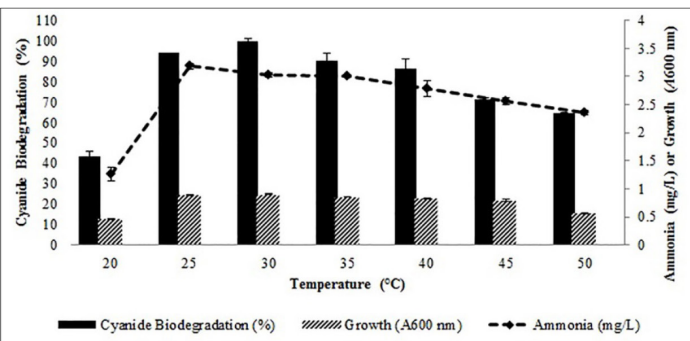

(e)

Figure 3. Optimization conditions for potassium cyanide biodegradation by K. oxytoca (a) Incubation day; (b) Cyanide Concentration; (c) Rotation Speed; (d) pH and (e) Temperature.

strain degraded over $70 \%$ of the cyanide content in the biodegradation media between the incubation temperatures of $25-45^{\circ} \mathrm{C}$ too (Figure 3e). Therefore, these results also indicated that enzymes of $K$. oxytoca synthesize effectively in different temperatures and it is seen as advantageous for using $K$. oxytoca strain in cyanide biodegradation processes which requires both of low and high temperatures.
Steel, coal and mining industries discharge wastes including heavy metals such as nickel, copper, iron and zinc $[25,26]$. Therefore, it is significant to select stable microorganisms in order to biodegrade cyanide in the presence of different ions in variable concentrations. In different researches, it is observed that, arsenic, 


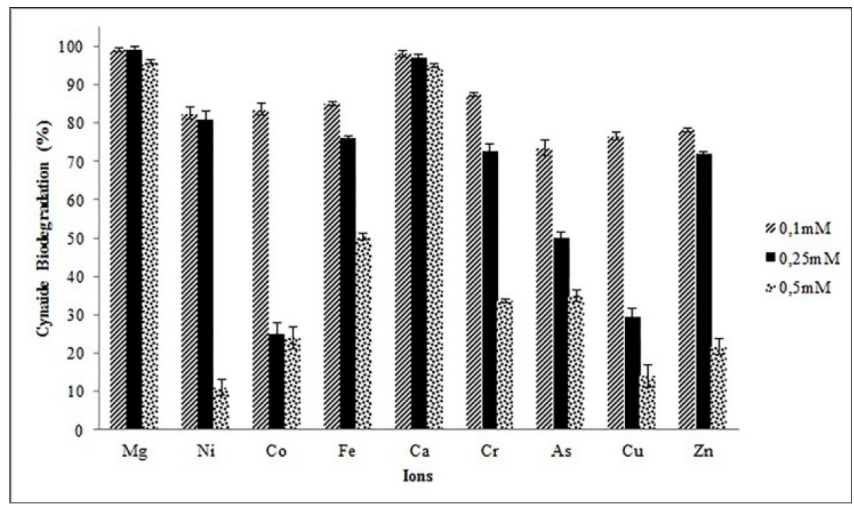

(a)

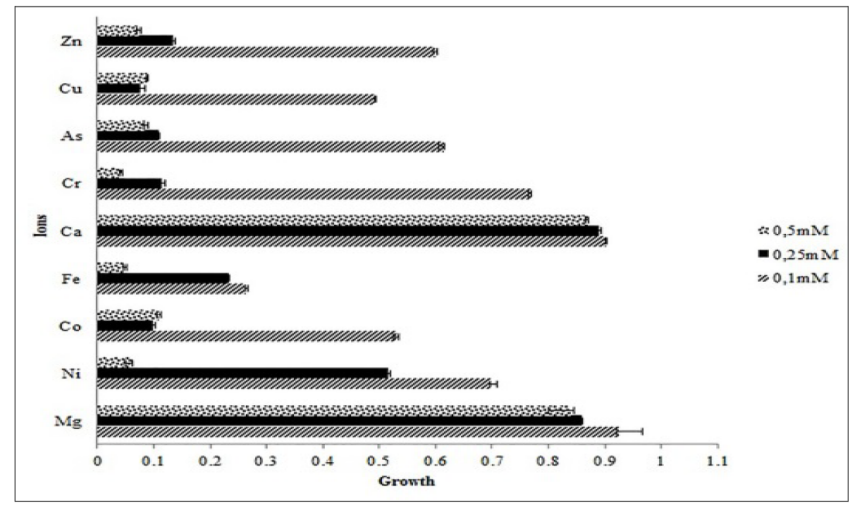

(b)

Figure 4. Effects of different ions on (a) potassium cyanide biodegradation, (b) growth.

(Mg: Magnesium; Ni: Nickel; Co: Cobalt; Fe: Iron; Ca: Calcium; Cr: Chromium; As: Arsenic; Cu: Copper; Zn: Zinc).

copper, iron and zinc are effective heavy metals on bacterial growth and bacterial enzymes for degradation processes $[6,18]$. Additionally, in a previous study it is found that cyanide degradation by Burkholderia cepacia directly correlates with the concentrations of $\mathrm{Ni}, \mathrm{Co}, \mathrm{Mn}$ and Mo ions [27]. In another study, it is found that $\mathrm{Ni}, \mathrm{Cu}$ and $\mathrm{Zn}$ ions didn't affect cyanide biodegradation but 20\% inhibition was observed in the presence of $\mathrm{Pb}$ and Cd ions and $30-35 \%$ inhibition was also observed in the presence of Fe by a bacterial consortium [21]. In a different study, it is found that in the presence of $\mathrm{Cu}$ and $\mathrm{Ca}$, growth and cyanide degradation of a bacterial consortium were also inhibited. However, when $\mathrm{Mg}$ and $\mathrm{Mn}$ are used, the growth amount didn't affect from these ions but cyanide degradation decreased [23]. In this study, $K$. oxytoca degraded potassium cyanide even in the presence of different concentrations $(0.1 \mathrm{mM}$, $0.25 \mathrm{mM}$ and $0.5 \mathrm{mM})$ of all ions $(\mathrm{Mg}, \mathrm{Ni}, \mathrm{Co}, \mathrm{Fe}$, $\mathrm{Ca}, \mathrm{Cr}, \mathrm{As}, \mathrm{Cu}$ and $\mathrm{Zn}$ ) and the growth amount of
K. oxytoca decreased as the ion concentrations increased (Figure $4 \mathrm{a}$ and Figure 4b). In this respect, results indicate that our strain is capable of degrading cyanide compounds in the presence of different concentrations of variable ions and as a result this strain may be used in biodegradation processes of cyanide contaminated areas.

Microorganisms degrade different compounds by synthesizing intracellular and extracellular enzymes. Therefore, not only bacterial cultures but also bacterial crude extracts are also effective in biodegradation processes. In the literature, among all Klebsiella species, $K$. ozaneae is the first investigated species for degrading cyanide with its extracellular enzyme called cyanide hydratase [28]. In this study, it is found that $73.5 \%$ of the cyanide content in the biodegradation media including sterile crude extract with a concentration of $5: 10(\mathrm{v}: \mathrm{v})$ was degraded in the first 24 hours. Additionally, fully degradation 


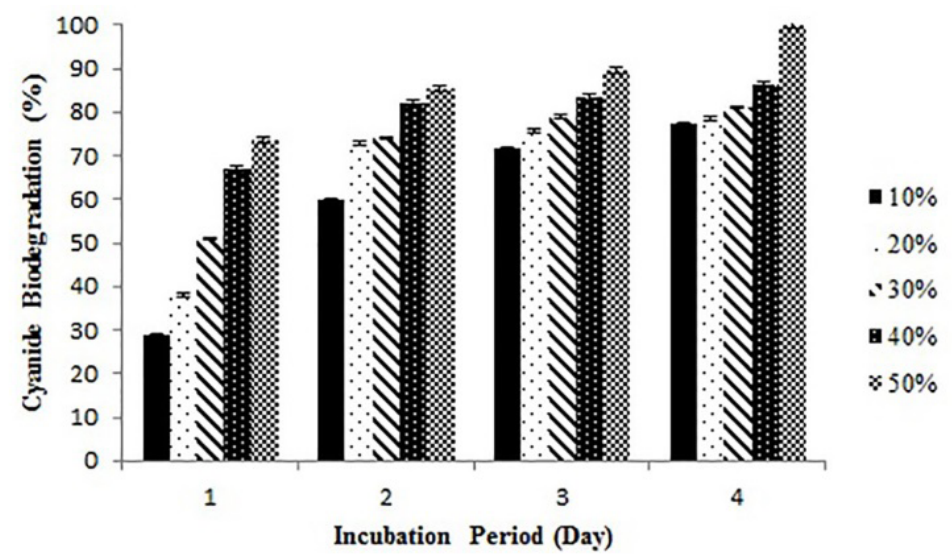

Figure 5. Biodegradation capability of sterile crude extract of $K$. oxytoca.

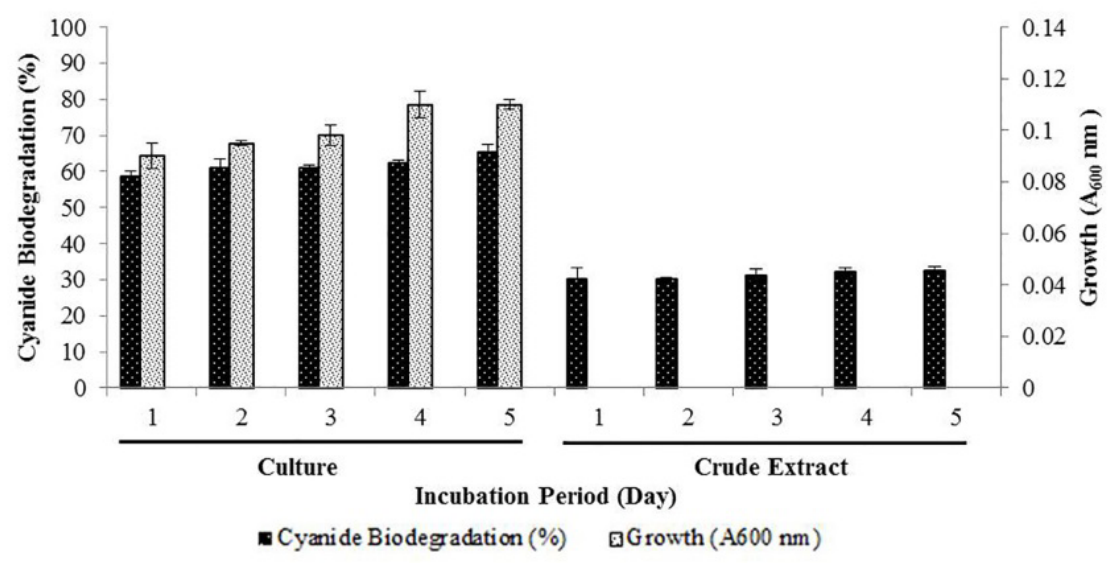

Figure 6. Cyanide removal in $6 \mathrm{mgkg}^{-1} \mathrm{cyanide}$ containing soil media with cultures and sterile crude extracts $K$. oxytoca.

was observed at the end of the $4^{\text {th }}$ day of the incubation period (Figure 5). In this respect, it is observed that sterile crude extract of $K$. oxytoca is also active in cyanide biodegradation process.

Accordingly, it is the first report for the extracellular enzyme of $K$. oxytoca in cyanide biodegradation process and it may be served as a source for future analysis of cyanide biodegradation by using extracellular enzyme of K. oxytoca.

Soil includes a wide range of organic and inorganic cyanide compounds as well as other organic and inorganic substances in its content [29]. Due to the usage of cyanide containing substances in daily life such as road salts and fire retardants and production of cyanide by a wide range of plants, algae and animals, cyanide accumulation in nature is increasing day by day [29-33]. Accordingly, accumulation of cyanide in soil and water may cause serious health risks on living organisms. Therefore, it is very important to take precautions for removal of cyanogen compounds. In this respect, in situ and ex situ cyanide removal techniques are being used in bioremediation of toxic substances in soil and other environmental areas. In this respect, biodegradation efficiencies of $K$. oxytoca's culture and sterile crude extract on cyanide containing soil samples were also investigated in this study. As a result, it is found that K. oxytoca culture $(65 \%)$ is more efficient than the sterile crude extract (33\%) in the cyanide removal of 6 $\mathrm{mgkg}^{-1}$ cyanide containing soil sample (Figure 6). Additionally, when cyanide removal in $240 \mathrm{mgkg}^{-1}$ 


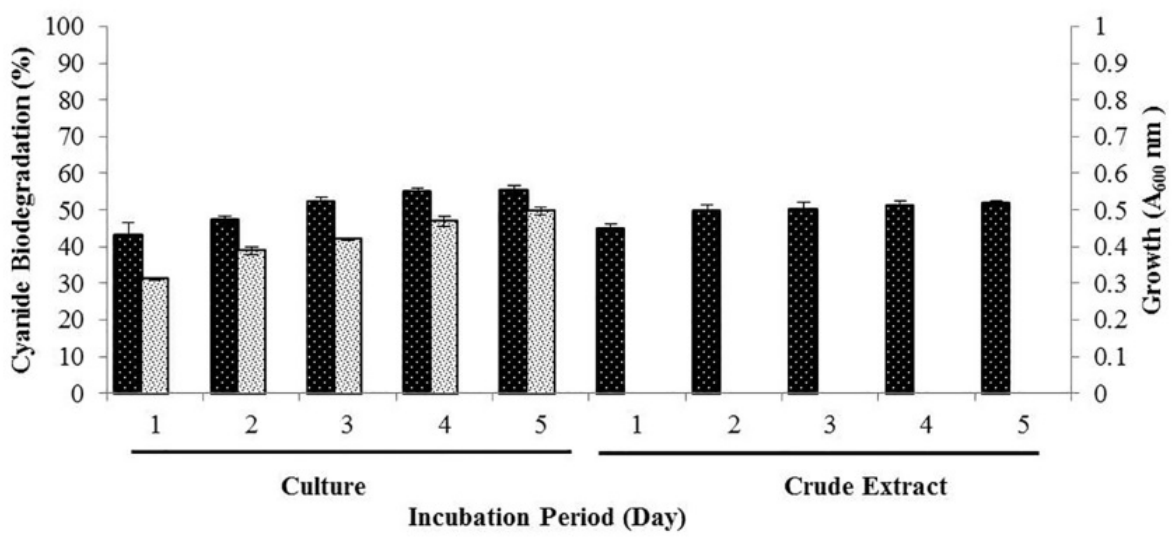

- Cyanide Biodegradation (\%) घGrowth (A600 nm)

Figure 7. Cyanide removal in $240 \mathrm{mg}^{\mathrm{kg}}{ }^{-1}$ cyanide containing soil media with cultures and sterile crude extracts of $\mathrm{K}$. oxytoca.

cyanide containing soil sample is investigated, it is examined that both of the culture and sterile crude extract are also effective (55\% and $52 \%$, respectively) in cyanide removal (Figure 7). Accordingly, it is observed that both of $K$. oxytoca's culture and sterile crude extract are efficient in the cyanide degradation of $6 \mathrm{mgkg}^{-1}$ and $240 \mathrm{mgkg}^{-1}$ cyanide containing soil samples. In literature, cyanide containing soil samples are generally treated by phytoremediation agents such as Sorghum bicolor, Linum usitassium [34], Eichornia crassipes [35], Salix babylonica [36] and Zea mays [37]. In parallel with our research, in another study it is found that Bacillus subtilis and Pseudomonas stutzeri degraded cyanide in soil $(0.218 \mathrm{mg} / \mathrm{g}$ cyanide/soil) with the percentages of $66.9 \%$ and $72 \%$ in 10 days, respectively [38]. In this respect, $K$. oxytoca culture and sterile crude extract may be used in bioremediation of cyanide in contaminated areas too.

\section{CONCLUSION}

The results of this research demonstrated the importance of $K$. oxytoca in the removal of different cyanide compounds, stability against increasing cyanide concentration, $\mathrm{pH}$ and temperature, different concentrations of variable ions in cyanide degradation processes. Additionally, different than other researches, sterile crude extract of $K$. oxytoca was used in cyanide biodegradation processes. In this respect, the results of this study are also promising for the future researches on $K$. oxytoca strain's usability to degrade cyanide wastes contaminated with different concentrations of heavy metals by using its culture or crude extract.

\section{ACKNOWLEDGEMENT}

This work is a part of PhD Thesis of N.H. Avcioglu and is funded by Hacettepe University Scientific Research Projects Coordination Unit (Project number: 014 D03 601 004).

\section{References}

1. M. Perumal, J.J. Prabakaron, M. Kamaraj, Isolation and characterization of potential cyanide degrading Bacillus nealsonii from different industrial effluents, International J. Chem. Tech. Res., 5 (2013) 2357-64.

2. V.M. Luque-Almagro, M.J. Huertas, M. MartinezLuque, C. Moreno-Vivian, M.D. Roldan, L.G. Garcia-Gil, F. Castillo, R. Blasco, Bacterial degradation of cyanide and its metal complexes under alkaline conditions, Appl. Environ. Microbiol., 71 (2005) 940-47.

3. R.R., Dash, A. Gaur, C. Balomajumder, Cyanide in industrial wastewaters and its removal: A review on biotreatment, J. Hazard. Mater., 163 (2009) 1-11.

4. A. Bilgin, E. Hasdemir, A. Murathan, Investigation of adsorption parameter effects on the removal of cyanide in water using clinoptilolite, Fresen. Environ. Bull., 23 (2014) 3222-26.

5. G. Asgari, A.M.S. Mohammadi, A. Poormohammadi, M. Ahmadian, Removal of cyanide from aqueous solution by adsorption onto bone charcoal, Fresen. Environ. Bull., 23 (2014) 720-27.

6. C.M. Kao, J.K. Liu, H.R. Lou, C.S. Lin, S.C. Chen, Biotransformation of cyanide to methane and ammonia by Klebsiella oxytoca, Chemosphere, 50 (2003) 1055-61. 
7. C.Y. Chen, C.M. Kao, S.C. Chen, Application of Klebsiella oxytoca immobilized cells on the treatment of cyanide wastewater, Chemosphere, 71 (2008) 133 39.

8. A.Y. Dursun, A. Çalık, Z. Aksu, Degradation of ferrous (II) cyanide complex ions by Pseudomonas fluorescens, Process Biochem., 34 (1999) 901-8.

9. K.D. Chatpawala, G.R.V. Babu, O.K. Vijaya, K.P. Kumar, J.H. Wolfram, Biodegradation of cyanides, cyanates and thiocyanates to ammonia and carbon dioxide by immobilized cells of Pseudomonas putida, J. Ind. Microbiol. Biot., 20 (1998) 28-33.

10. P. Kaewkannetra, T. Imai, F.J. Garcia-Garcia, T.Y. Chiu, Cyanide removal from cassava mill waste water using Azotobacter vinelandii TISTR 1094 with mixed microorganisms in activated sludge treatment system, J. Hazard. Mater., 172 (2009) 224-28.

11. P.R. Meyers, P. Gokool, D.E. Rawlings, D.R. Woods, An efficient cyanide degrading Bacillus pumilus strain, J. Gen. Microbiol., 137 (1991) 1397-1400.

12. M. Santoshkumar, Y. Veeranagouda, K. Lee, T.B. Karegoudar, Utilization of aliphatic nitrile by Paracoccus sp. SKG isolated from chemical waste samples, Int. Biodeter. Biodegr., 65 (2011) 153-59.

13. N.H. Avcioglu, Investigation of Cyanide Biodegradation by Different Klebsiella Strains, PhD thesis (2016), Hacettepe University Faculty of Science, Ankara, Turkey.

14. F.B. Fishier, J.S. Brown, Colorimetric determination of cyanide in stack gas and waste water, Anal. Chem., 24 (1952) $1440-44$.

15. A.E. Greenberg, L.S. Clesceri, A.D. Eaton, Standard Methods for the water and waste water, Denver, C.O. USA: American Public Health Association, American Water Works Association and Water Environment Federation, (1992) 1137.

16. C.Y. Chen, C.M. Kao, S.C. Chen, T.Y. Chen, Biodegradation of tetracyanonickelate by Klebsiella oxytoca under anaerobic conditions, Desalination, 249 (2009) 1212-16.

17. H. Yanase, A. Sakamoto, K. Okamoto, K. Kita, Y. Sato, Degradation of the metal-cyano complex tetracyanonickelate(II) by Fusarium oxysporum N-10, Appl. Microbiol. Biot., 53 (2000) 328-34.

18. A.Y. Dursun, Z. Aksu, Effect of internal diffusivity of ferrous(II) cyanide complex ions in Ca-alginate immobilized Pseudomonas fluorescens gel beads on the biodegradation rate, Process Biochem., 37 (2002) 747-52.

19. S. Potivichayanon, R. Kitleartpornpairoat, Biodegradation of cyanide by a novel cyanidedegrading bacterium, World Academy of Science, Engineering and Technology, 42 (2010) 1362-65.

20. C. Wang, D.A. Kunz, B.J. Venables, Incorparation of molecular oxygen and water during enzymatic oxydation of cyanide by Pseudomonas fluorescens NCIMB 11764, Appl. Environ. Microb., 62 (1996) 219597.

21. Y.B. Patil, K.M. Paknikar, Development of a process for detoxification of metal cyanides from waste waters, Process Biochem., 35 (2000) 1139-51.
22. H.K., Kwon, S.H. Woo, J.M. Park, Degradation of tetracyanonickelate(II) by Cryptococcus humicolus MCN2, FEMS Microbiol. Lett., 214 (2002) 211-16.

23. A. Sankaranarayanan, M. Gowthami, Cyanide degradation by consortium of bacterial species isolated from sago industry effluent, Journal of Environmental Treatment Techniques, 3(2015), 41-46.

24. V. Kumar, V. Kumar, T.C. Bhalla, In vitro cyanide degradation by Serratia marcescens RL2b, International J. Environ. Sci., 3 (2013) 1969-79.

25. Z. Aksu, A. Çalık, A.Y. Dursun, Z. Demircan, Biosorption of iron(III) cyanide complex anions to Rhizopus arrhizus: application of adsorption isotherms, Process Biochem., 34 (1999) 483-91.

26. M.R. Samarghandi, M. Ahmadian, J. Mehralipur, A. Shabanlo, A. Poormohammadi, Studies on removal of cyanide from aqueus environments using aluminum electrodes, Fresen. Environ. Bull., 23 (2014) 613-19.

27. M.D. Adjei, Y. Ohta, Factors effecting the biodegradation of cyanide by Burkholderia cepacia strain C-3, J. Biosci. Bioeng., 89 (2000) 274-77.

28. P. Parmar, A. Soni, P. Desai, Enzymatic study of cyanide utilizing Pseudomonas species isolated from contaminated soil, Journal of Scientific and Innovative Research, 2 (2013) 1058-66.

29. J. Baxter, S.P. Cummings, The current and future applications of microorganism in the bioremediation of cyanide contamination, Antonie van Leeuwenhoek, 90 (2006) 1-17.

30. C.J. Knowles, Microorganisms and cyanide, Bacteriol. Rev., 40 (1976) 652-80.

31. M. Zagrobelny, S. Bak, B.L. Moller, Cyanogenesis in plants and arthropods, Phytochemistry, 69 (2008) 1457-68.

32. R.J. Kremer, T. Souissi, Cyanide production by Rhizobacteria and potential for suppression of weed seedling growth, Curr. Microbiol., 43 (2001) 182-86.

33. G.M. Wong-Chong, D.V. Nakles, R.G. Luthy, Manufacture and the Use of Cyanide. In: D.A. Dzombak, R.S. Ghosh, G.M. Wong-Chong, editors. Cyanide in Water and Soil, Chemistry, Risk and Management. Boca Raton: Taylor\&Francis, Vol. 4 (2006), 43-44.

34. L.Y. Hong, M.K. Banks, A.P. Schwab, Removal of cyanide contaminants from Rhizosphere Soil, Bioremediation J., 12 (2008) 210-15.

35. M. Ebel, M.W.H. Evangelou, A. Schaeffer, Cyanide phytoremediation by water hyacinths (Eichornia crassipes), Chemosphere, 66 (2007) 816-23.

36. X.Z. Yu, J.D. Gu, L. Li, Assimilation and physiological effects of ferrocyanide on weeping willows, Ecotoxical Environ. Safe., 71 (2008) 609-15.

37. X.Z. Yu, JD. Gu, Differences in Michaelis-Menten kinetics for different cultivars of maize during cyanide removal. Ecotox. Environ. Safe., 67 (2007) 254-59.

38. O. Nwokoro, M.E.U. Dibua, Degradation of soil cyanide by single and mixed cultures of Pseudomonas stutzeri and Bacillus subtilis, Archives of Industrial Hygiene and Toxicology, 65 (2014) 113-19. 
